\title{
HAGGAI: MASTER RHETORICIAN
}

\author{
M.J. Boda
}

\section{Summary}

Although the prophet among the Book of the Twelve with the fewest words, save Jonah, Haggai takes his place among the prophetic tradition as one of its greatest rhetoricians. Utilising historical critical techniques, past scholars have often explained literary features in Haggai as evidence of the compilation of various sources and forms. This article reconsiders this evidence and argues that the same evidence reveals creative rhetorical technique. Several instances of this technique are explored and this study reveals the prophet's sensitivity to influence the intended audience, creativity to sustain the audience's interest and delay tactics to produce greater impact on the audience. Some of the trends identified are traced to the prophetic tradition in general, others to the Persian Period prophetic tradition, while others are seen as unique to this book.

The past year, as we have lived through the transition from one century to another, has seemed like one long retrospect over the heights and depths of the 20th century. Although many have reached saturation point because of the overuse of this retrospective genre, it is an appropriate exercise for all, especially for those whose focus is the study of the Bible.

This past century began with historical critical methods widely accepted as the appropriate tools for accessing the meaning of the ancient biblical texts. Source, Form, Tradition, and Redaction Criticism were designed to provide clear windows for observing the origins of a text and these underlying origins were considered the locus of meaning. Near the middle of the century, however, these diachronic methods were forced to share centre stage with emerging synchronic approaches. These approaches, including Rhetorical and Canonical Criticism and influenced by New Criticism and Structuralism, focused more attention on the structure of the text itself in its final form rather than searching for meaning in the earlier stages of the development of the text. In more recent years, however, 
the stage has become crowded with the introduction of Reader Response, Feminist and Postmodern approaches, focusing more attention on the modern reader of the ancient text. This century has been witness to oft times confusing, always controversial shifts in the way in which scholars handle biblical texts, shifts which have moved the guild from focusing on the world behind the text to the world before the text. 1

With these hermeneutical shifts has come a greater appreciation of the role of the audience in the communication act and their participation in the creation of meaning. The audience was often lost in the diachronic search for the origins of biblical works as scholars sought for those responsible for speaking and writing these ancient texts. In synchronic and postmodern hermeneutical strategies a much greater role is afforded the audience, especially the modern reader.

A study of various scholarly contributions to the book of Haggai displays the excesses of a diachronic approach to the biblical text. Employing skills from the disciplines of Source, Form and Redaction Criticism, scholars have focused increasingly on smaller and smaller pieces of the prophetic book. ${ }^{2}$ Haggai was especially challenging

1 Admittedly, this is a simplistic overview of the ebb and flow of biblical scholarship in a fascinating century. For further reflection see S.E. Gillingham, One Bible, Many Voices: Different Approaches to Biblical Studies (Grand Rapids: Eerdmans, 1998); R. Morgan and J. Barton, Biblical Interpretation (Oxford: OUP, 1988); the succinct overview in T. Longman III, Literary Approaches to Biblical Interpretation (Foundations of Contemporary Interpretation 3; Grand Rapids: Zondervan, 1987); and the excellent reference series Guides to Biblical Scholarship edited by Dan Via (NT) and Gene Tucker (OT) and published by Fortress Press (Philadelphia). The designations of the world behind, within and before the text are adapted from W.R. Tate, Biblical Interpretation: An Integrated Approach (Peabody: Hendrickson, 1991).

2 Examples of this atomistic approach are many. For the entire book of Haggai see the analysis of F.S. North, 'Critical Analysis of the Book of Haggai', $Z A W 68$ (1956), 25-46. North's reductionistic approach shrinks the book to a fraction of its final form. For Haggai 1 see O.H. Steck, ' $Z u$ Haggai 1:2-11', $Z A W 83$ (1971), 355-79, who used form critical methods to identify 1:4-8 as a saying addressing Judeans who had remained in the land during exile (people have houses) and 1:9-11 as addressing those who returned from Babylon (people busy with houses). D.L. Petersen (Haggai and Zechariah 1-8 [OTL; Philadelphia: Westminster, 1984], p. 49) identifies 1:1-2 as part of an original message to Zerubbabel and Jeshua which has been fused with 1:3-11 which was originally addressed to the people as a whole. Cf. R.A. Mason (Preaching the Tradition: Homily and Hermeneutics after the Exile [Cambridge: CUP, 1990], pp. 186; 286, n. 6) for an excellent review of the debate over the unity/disunity of this pericope. H.W. Wolff (Haggai: $A$ Commentary [Tr. M. Kohl; Minneapolis: Augsburg, 1988], p. 72) describes Haggai 2:1-9 in the following way: 'All in all, therefore, we do not find here 
because of the high percentage (odd among the prophetic books) of editorial text surrounding a short prophetic message. ${ }^{3}$ Furthermore the book has a high number of messenger formulae, not restricted merely to the beginning and end of pronouncements but also interjected in the centre. ${ }^{4}$ Finally, inconsistency in certain aspects of the editorial text invited speculation over the diverse origins of the material or variety of levels in the redaction of the book. ${ }^{5}$

While the goal of this study is not to disqualify diachronic attempts to distinguish between the literary and oral aspects of the book of Haggai, nor to brush over some of the challenging literary issues in a simplistic manner, the hope is that a greater appreciation of Haggai's oral rhetoric will inform this discussion and display more clearly the unity of much of the oral material in the book. At the outset the focus will be on those rhetorical techniques used in Haggai which are shared by other prophetic books and especially those of the Persian period. Then attention will turn to unique techniques that are used by the prophet to communicate his message.

Haggai stands near the end of a long tradition of prophetic expression in the Hebrew community. His place in that tradition

what form criticism would see as a self-contained discourse', denigrating its integrity by identifying 'clumsy or disjointed transitions'. What this means is that Haggai does not meet the stock forms Wolff has in his mind as he approaches the text. Probably the greatest example of this trend is displayed in the controversy surrounding 2:10-14. Beginning with J.W. Rothstein (Juden und Samaritaner [Leipzig: Hinrich, 1908]), some have gone to the point where they have moved the material to a different place. Pfeill has written what is unquestionably the best review of the issue, demonstrating how this theory of Rothstein became a working assumption among scholars of Haggai until re-examination revealed its bankruptcy ("When is a Gôy a "Gôy"? The Interpretation of Haggai 2:10-19', in W.C. Kaiser, Jr. and R.F. Youngblood, eds., A Tribute to Gleason Archer [Chicago: Moody Press, 1986], pp. 261-78). The influence of Rothstein's theory is displayed in Wolff's commentary on Haggai which places the interpretation of 2:15-19 after that of 1:1-14.

3 The editorial third person material encompasses $25 \%$ of the book as compared with $59 \%$ for the oral pieces.

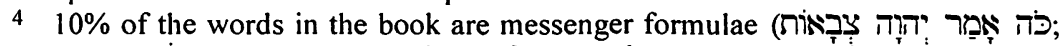

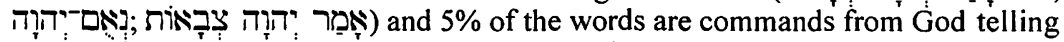
the prophet to tell someone something. See also J.E. Tollington, Tradition and Innovation in Haggai and Zechariah 1-8 (JSOTSup 150; Sheffield: JSOT, 1993), p. 65.

5 In particular there are two different ways of introducing the fact that Haggai

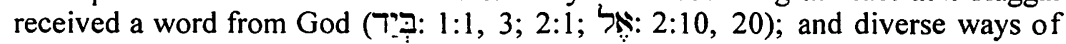
presenting date formula (YEAR-MONTH-DÄY: 1:1; DAY-MONTH-YEAR: 1:15; 2:10; MONTH-DAY: 2:1; DAY-MONTH: 2:18, 20). For the impact of the latter on redaction criticism see Wolff (Haggai, p. 59) as an example. 
influences the way in which he communicates his message as he reflects several trends from the latter period of the prophetic institution.

One feature of the book of Haggai, already mentioned above, that has created suspicion over the unity of the oral material is the constant interjection of messenger formulae. For many readers this grates against their modern sensibilities, especially those in Western contexts where rhetoricians are concerned with simple and direct speech. Is this the work of a later redactor or does it originate with the prophet himself? To answer this question necessitates a comparison of the use of messenger formulae in the various prophetic books.

\begin{tabular}{|c|c|c|}
\hline & \multicolumn{2}{|c|}{ Occurrences per verse of phrase } \\
\hline Biblical book & אָמֵר :יהוָה & 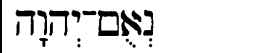 \\
\hline Isaiah 1-39 & .01 & .01 \\
\hline Isaiah 40-55 & .06 & .02 \\
\hline Isaiah 56-66 & .06 & .02 \\
\hline Jeremiah & .04 & .05 \\
\hline Ezekiel & .002 & .003 \\
\hline Hosea & 0 & .02 \\
\hline Joel & .01 & .01 \\
\hline Amos & .13 & .1 \\
\hline Obadiah & 0 & .09 \\
\hline Micah & .02 & .02 \\
\hline Nahum & 0 & .04 \\
\hline Habakkuk & 0 & 0 \\
\hline Zephaniah & .02 & .09 \\
\hline Haggai & .21 & .31 \\
\hline Zechariah 1-8 & .19 & .1 \\
\hline Zechariah 9-14 & .01 & .08 \\
\hline Malachi & .45 & .02 \\
\hline
\end{tabular}

Nearly all books in the Latter Prophets use messenger formulae at some point. However, several of them stand out for their repeated use. As can be seen in the chart above, Haggai, Zechariah 1-8 and Malachi have the top three ratios for using these formulae. This shows us, at the least, that Haggai's use of messenger formulae is a 
feature of the Persian Period and thus not necessarily evidence of editorial reworking.

What is the rhetorical purpose of these interjections? The higher percentage in the book of Amos may offer a suggestion. This prophet struggled with the issue of the authority and authenticity of his prophetic words at least once during his career. ${ }^{6}$ If this is the cause of these higher percentages, it appears that, on the level of rhetoric, the constant interjection of messenger formulae may be evidence of a desire to assure the hearers that God is speaking. The extreme crisis in prophecy in Amos' day created the need for these consistent reminders. This may be a window into a sceptical attitude of the Persian community towards prophecy that may have been fostered by the late pre-exilic crisis in the prophetic movement. ${ }^{7}$

A second rhetorical strategy seen consistently throughout Haggai's work and reflecting a trend of the Persian Period prophetic movement is the use of interrogatives to draw in the audience (cf. Zc. 1:5, 6; 7:5-7; Malachi passim). ${ }^{8}$ Haggai uses this strategy at his first opportunity as he turns from the leadership to the people at large in $1: 4$. He will use a question again in 1:9, at a crucial turning point in the prophetic message of chapter 1 (see further below), a series of three in 2:3, two more in $2: 12-13$ and a final one in 2:19. The interrogative mood engages the audience in a powerful way, forcing

6 For an excellent review of the scholarly interpretation of the confrontation between Amaziah and Amos see G.V. Smith, Amos: A Commentary (Grand Rapids: Zondervan, 1989), pp. 236-43; see also J.D.W. Watts, Vision and Prophecy in Amos (Leiden: Brill, 1958), pp. 1-30; G.M. Tucker, 'Prophetic Authority: A Form-critical Study of Amos 7:10-17', Interpretation 27 (1973), 423-34; Z. Zevit, 'A Misunderstanding at Bethel: Amos VII 12-17', VT (1975), 783-90; Y. Hoffmann, 'Did Amos Regard Himself as a nabi '?', VT 27 (1977), 209-212; H.W. Wolff, Joel and Amos (Hermeneia; tr. W. Janzen, W.D. McBride, C.A. Muenchow; Philadelphia: Fortress, 1977), pp. 306-316; S.M. Paul, Amos: A Commentary on the Book of Amos (Hermeneia; Minneapolis: Fortress, 1991), 238-52.

7 Jeremiah also faced opposition from false prophets and does use the messenger formulae the most of any prophet in the Latter Prophets (65 for

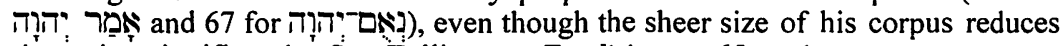
the ratios significantly. See Tollington, Tradition, p. $65, \mathrm{n} .1$.

8 See B.O. Long, 'Two Question and Answer Schemata in the Prophets', JBL 90 (1971), 129-39, and J.W. Whedbee, 'A Question-Answer Schema in Haggai 1: The Form and Function of Haggai 1:9-11', in G.A. Tuttle, ed., Biblical and Near Eastern Studies: Essays in Honor of William Sanford Lasor (Grand Rapids: Eerdmans, 1978), pp. 184-94, for further discussion of the roots of this form type, although its use in the Persian period takes on an altered style. Verhoef reveals differences between the dialogues in Haggai and Malachi, but this does not eradicate the general trend of this period (P.A. Verhoef, The Books of Haggai and Malachi [NICOT; Grand Rapids: Eerdmans, 1987], p. 45). 
them to reflect on the message in a deeper measure than in mere pronouncements. It is used by Haggai both to bring judgement (1:4, $9 ; 2: 12-13,19)$ and to express sympathy $(2: 3){ }^{9}$

A third rhetorical strategy is shared not with the Persian Period books as much as with the prophets of the late pre-exilic and early exilic period: Jeremiah and Ezekiel. This rhetorical technique quotes a saying among the people that is then promptly refuted by the prophet (cf. Je. 2:5, 14, 23, 28, 29, 36; 31:29; Ezk. 12:22-25, 26-28; 18:12). ${ }^{10}$ Haggai uses this technique masterfully at the outset of his message in Haggai 1:2, where in the hearing of the leadership (Zerubbabel, Jeshua) he cites the attitude of the people towards the rebuilding project.

To this point Haggai's rhetorical techniques are attested in the later period of prophetic expression. But there are a few techniques that Haggai employs which are unique to him. Most of these employ features of rhetorical technique already covered above, but do so in

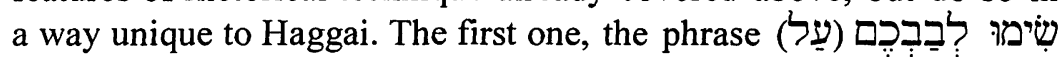
$(1: 5,7 ; 2: 15,18)$ is unique to Haggai. ${ }^{11}$ This idiom calls the audience to deep reflection over past behaviour and experience. Its occurrence in 1:5 and 7 creates an envelope around the exposure of past experience. 12

9 Both Pierce and Craig have exploited these question styles for redactional ends, suggesting that they point to the unity of Haggai-Zechariah-Malachi (Pierce) or at least Haggai-Zechariah (Craig, although see his note: p. 244, n. 33). The difficulty with these arguments is that the question styles are much too diverse for a common editor. Cf. R.W. Pierce, 'Literary Connectors and a Haggai-Zechariah-Malachi Corpus', JETS 27 (1984), 277-89; K.M. Craig, Jr., 'Interrogatives in Haggai-Zechariah: A Literary Thread?', in P.R. House and J.W. Watts, eds., Forming Prophetic Literature: Essays on Isaiah and the Twelve in Honor of John D.W. Watts (Sheffield: Sheffield Academic Press, 1996), pp. 224-44.

$10 \mathrm{Cf}$. T.W. Overholt, 'Jeremiah 2 and the Problem of Audience Reaction', $C B Q 41$ (1979), 262-73.

11 Although a portion of it is found in Jb. 1:8 and Is. 41:22.

12 Following Whedbee ('Question-Answer Schemata') who correctly sees the word 'ways' in 1:5, 7 as referring to past activity not future activity. This view

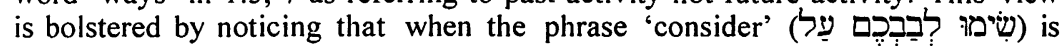
used in Haggai (2:15-19) and takes into account past and future, the word 'ways' is dropped. The view taken here stands in contrast to P.L. Redditt, Haggai, Zechariah, Malachi (Grand Rapids: Eerdmans, 1995), p. 20; Petersen, Haggai, p. 51; H.G. Mitchell, Haggai and Zechariah (ICC; Edinburgh: T. \& T. Clark, 1912), p. 47, who see the second appearance as introducing the imperatives in 1:8 (future action). This second judgement is based on the view that the clause: 'This is what the Lord Almighty says' is an introductory phrase not a concluding one. But this view fails to take into account that $1: 7 \mathrm{a}$ is introducing a declaration: 'Give careful thought to your ways.' 
The second strategy unique to Haggai is one often mistakenly identified as evidence of disunity in the book. In Haggai 1 the prophet begins by identifying two different issues relevant to his community. The first issue is expressed through two of the previously discussed rhetorical strategies: quotation and interrogative. Playing off the leitmotif of 'time', Haggai is told to express God's concern over the priorities of the people (1:2-4). Without a smooth transition, Haggai then introduces a second issue

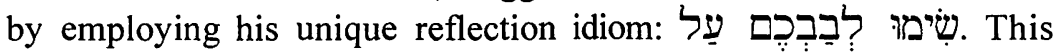
issue focuses the people's attention on the hardships they have experienced in recent times (1:5-7). To this point these two issues are not related in any direct way. It is not until the audience passes over the three crucial commands in 1:8 (בנה ,בוא, עלה) with supporting causal phrases (כבד ,רצה) that the two issues are linked. This is done in 1:9-11 by picking up the second issue introduced

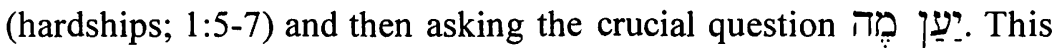
question is used to link the issue of hardship with the initial issue of priorities. What appeared to many scholars as roughness reflecting various layers in the text, actually is evidence of powerful rhetorical technique..$^{13}$ By not directly linking the two issues, Haggai allows the two to sink in more deeply. It also allows him to tell them what the required response is $(1: 8)$ before the final blow is administered in this judgement section.

Haggai employs another technique in his second major speech in 2:1-9. Facing an audience discouraged and possibly also disgruntled by slow progress in the early stages of the project, the prophet begins his positive message with a series of questions $(2: 3)$. The first question begins on an objective level, asking who remained of those who saw the former temple. The second question subtly moves the discussion from the objective to the subjective level, sensitively probing the deeply seated attitudes of the people towards the project. The third question takes this a final step and reveals that the prophet understands their subjective reaction, justifying such discouragement. This technique grants the prophet an audience with the people and sets the tone for this crucial message of hope.

Haggai continues this trend of sensitively accommodating his message to his particular audience in the following pericope utilising a fourth rhetorical technique. In 2:10-14, the prophet engages the priests by employing a familiar speech form (the torah ruling) and

13 See n. 2 above. 
then using that form as the foundation for his main message. ${ }^{14}$ Although an odd form for the modern reader to understand, it is designed to draw the priests into dialogue and build a foundation for the following speech to the people as a whole. This torah ruling form also reflects another tendency of Haggai's rhetoric: that is, to question his audience and thus force them to consider deeply his thrust.

A final technique can be discerned in 2:15-19. This section already contains one of Haggai's unique strategies in the threefold

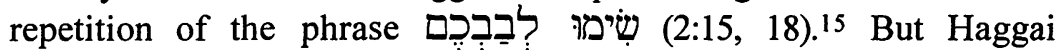
strengthens the rhetoric even further by employing another phrase

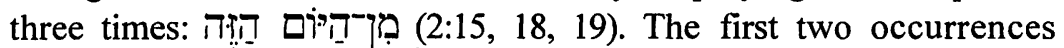
attach the Hebrew word in various ways due to what has been perceived as the awkward flow of this section. The usual translation of this Hebrew construction would be 'from this day on' (see 1 Sa. 16:13; 30:25) which many have rejected for this context in Haggai, because the occurrences in this passage are followed immediately by a reflection on the past. To resolve this apparent tension, some have translated this as 'from this day backward', representing a unique gloss in the Hebrew Bible. ${ }^{16} \mathrm{~A}$

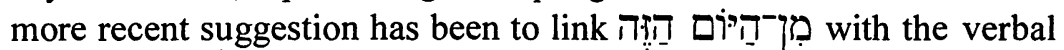

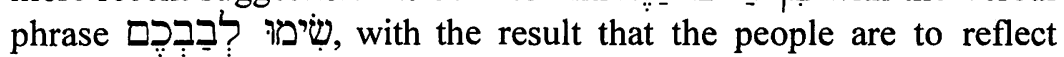
deeply from this day on. ${ }^{17}$ However, this would not apply to the third occurrence of 'from this day' which is not linked with 'give careful thought' (2:19).

The answer to this dilemma may lie in accepting this passage as a rhetorical masterpiece in which Haggai forces deeper thinking

14 The foundation of this form is seen in Lv. 10:10, 11; Dt. 17:8-13; 21:5; Ezk. 44:23-34, a responsibility demanded of the tribe of Levi in the Torah (cf. R. de Vaux, Ancient Israel: Religious Institutions [New York: McGraw-Hill, 1961], pp. 154, 354). Abuse of this responsibility is cited by the prophets: Mi. 3:11; Je. 18:18; Ezk. 7:26; 22:26; Zp. 3:4. See E.M. Meyers, 'The Use of tôrâh in Haggai 2:11 and the Role of the Prophet in the Restoration Community', in C.L. Meyers; M. O'Connor, eds., The Word of the Lord Shall Go Forth: Essays in Honor of David Noel Freedman in Celebration of His Sixtieth Birthday (Winona Lake: Eisenbrauns, 1983), pp. 69-76; also M. Fishbane, Biblical Interpretation in Ancient Israel (Oxford: Clarendon, 1985), p. 297.

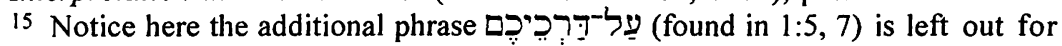
it restricts reflection to the past while in this pericope the reflection is to be past, present and future (see n. 12 above).

16 Cf. E.H. Merrill, An Exegetical Commentary: Haggai, Zechariah, Malachi (Chicago: Moody Press, 1994), pp. 49, 51, for this argument and Mitchell (Haggai, pp. 73-74) for arguments against.

17 D.J. Clark, 'Problems in Haggai 2:15-19', Bible Translator 34 (1983), 432. 
through introducing multiple thoughts at the same time. ${ }^{18}$ We have seen this technique in his first speech in which two ideas were presented but left unconnected until the second phase of the speech. Here in 2:15-19, the prophet begins a speech about the future three times, but each time interrupts himself by drawing attention to the past.

The result of this creative rhetoric is that the people are forced to think of the past, present and future simultaneously. It places great emphasis on the present with the repeated reference to ('the day') which is identified as the day of the foundation laying (five times; $2: 15,18,19)$. At the same time, however, the people are to

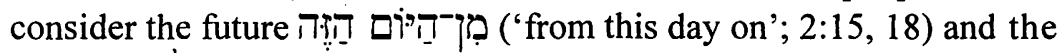

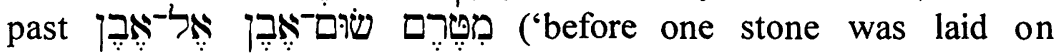
another'; $2: 15)$. Although more words are linked to the description of the frustrating past, greater emphasis is placed on the anticipated future by beginning and ending with a future time reference and constantly interrupting the full declaration of the future dimension. Most emphasis, however, is placed on the significance of the present day which functions as a linchpin between a past of curse and a future of blessing and calls the people to reflect deeply upon this thought. 19

As has been highlighted throughout this article, Haggai is a masterful rhetorician. He consistently expresses his words in ways

18 This is similar to but not identical to the view that we have here a parenthetical remark. Cf. D.R. Hildebrand, 'Temple Ritual: A Paradigm for Moral Holiness in Haggai II 10-19', VT 39 (1989), 164.

19 The significance of that day is that it is the day of the foundation laying. See the foundational research of R.S. Ellis, Foundation Deposits in Ancient Mesopotamia (New Haven: Yale University Press, 1968) which has been mined brilliantly by E. Lipiński, 'Recherches sur le livre de Zacharie', VT 20 (1970), 25-55; D.L. Petersen, 'Zerubbabel and Jerusalem Temple Reconstruction', $C B Q$ 36 (1974), 366-72; Petersen, Haggai, pp. 89-90; B. Halpern, 'The Ritual Background of Zechariah's Temple Song', $C B Q 40$ (1978), 171-72; R.E. Averbeck, 'Biblical Temple Building Accounts in Light of Ritual and Structure in the Gudea Cylinders', Society of Biblical Literature 1991 Seminar Papers (Atlanta: Scholars Press, 1991), 1-15; and A. Laato, 'Zachariah 4,6b-10a and the Akkadian Royal Building Inscriptions', ZAW 106 (1994), 53-69. Prior to publication of Ellis' 1965 dissertation, which does not make connections between Mesopotamian and Hebrew practices, Bewer, Galling and Petitjean had noted preliminary links between them. Cf. J.A. Bewer, 'Ancient Babylonian Parallels to the Prophecies of Haggai,' AJSLL 35 (1919), 128-33; K. Galling, 'Serubbabel und der Hohepriester beim Wiederaufbau des Tempels in Jerusalem', in Studien zur Geschichte Israels im Persischen Zeitalter (Tübingen: Mohr, 1964), pp. 127-48; A. Petitjean, 'La Mission de Zorobbabel et la Reconstruction du Temple', Ephemerides Theologicae Lovanienses 42 (1966), 40-71. 
accommodating to his audience. One consistent value for Haggai, displayed in many of the techniques he employs, is that of not allowing the audience from the outset to know where his message is going until it is absolutely necessary. This successfully creates a greater impact on them when the message is clarified.

Although the prophet among the Book of the Twelve with the fewest words, save Jonah, Haggai takes his place among the prophetic tradition as one of their greatest rhetoricians. Among a generation questioning the validity and future of the prophetic voice, Haggai bore witness for the Lord Almighty in creative and powerful ways. 